\title{
The first record of the genus Zomus Reddell \& Cokendolpher, 1995 (Schizomida: Hubbardiidae) from Samoa
}

\author{
Первая находка рода Zomus Reddell \& Cokendolpher, 1995 \\ (Schizomida: Hubbardiidae) на Самоа
}

\author{
Osvaldo Villarreal Manzanilla \\ О. Вияларреал Манзанимла
} Subproyecto 1/Red Nacional Antivenenos, Museo del Instituto de Zoología Agrícola, Facultad de Agronomía, Universidad Central de
Venezuela, Apartado 2101-A, ZP 4579, Maracay, Aragua Venezuela. E-mail: osvaldovillarreal@gmail.com

KEY WORDS: Hubbardiinae, corneate schizomids, Samoa.

КЛЮЧЕВЫЕ СЛОВА: Hubbardiinae, шизомиды с глазами, Самоа.

ABSTRACT. Zomus bagnallii (Jackson, 1908) is recorded for the first time from Samoa. One female and one immature were studied, the taxonomic characters are illustrated, and a complementary description is presented. This is the first record of any nominal species of the order Schizomida for this country and a new habitat is recorded for this species.

PЕЗЮМЕ. Zomus bagnallii (Jackson, 1908) впервые отмечен на Самоа. Были изучены одна половозрелая самка и одна неполовозрелая особь. Приведены описания особей. Z. bagnallii не только первый представитель семейства, но и первый представитель шизомид на острове и в стране. Кроме того указывается новый тип местообитаний для $Z$. bagnallii.

Zomus bagnallii (Jackson, 1908) is an eyed schizomid described from material collected in 1907 in the Royal Botanic Gardens, Kew, England, where it was doubtlessly introduced [Sissom, 1980; Cokendolpher et al., 1988]. However, it is a widespread species in south-east Asia, being known from Malaysia, Singapore, Cook Islands, Fiji, Mauritius [=island of Rodriguez], Seychelle Islands and Krakatau Islands in Indonesia [Reddell \& Cokendolpher, 1995; Harvey, 2001]. The lack of males in all populations of this species suggests that it may be facultatively parthenogenetic [Reddell \& Cokendolpher, 1995; Harvey, 2001].

The schizomid fauna of Samoa is unknown and only some records at familial or subfamilial levels are known [Savory, 1977; Reddell \& Cokendolpher, 1995]. In this note a new record of the order Schizomida for Samoa is presented, which represents the first record of any nominal schizomid species for this country.

The pattern of description follows Villarreal et al. [2008]. The specimens examined for this study are deposited in Museo del Instituto de Zoologia Agricola (MIZA), Maracay, Venezuela. The measurements are expressed in millimeters and were made using a Leica Wild M8 dissection stereomicroscope. The spermathecae were clarified in peroxide at $3 \%$ and then examined after immersion in glycerin for 24 hours, and were maintained together with the female in a microvial. The drawings were made using the software Adobe Illustrator CS2 and Inkscape. The pictures were made using a digital camera Nikon E5400, atachment to a Leica Wild M8.

\section{Zomus bagnallii (Jackson, 1908)} Figs 1-9.

MATERIAL EXAMINED. One female (MIZA 1355) and one immature (MIZA 1356). Samoa, Saleapaga Faofao, track to the plateau, 25-50 m, 28.xi.2008 (Hermes Escalona).

DESCRIPTION OF FEMALE. Dimensions (mm) Body length 11.61. Propeltidium 3.87/2.05. Pedipalps: trochanter 1.34 , femur 1.42 , patella 1.66 , tibia 1.42 , tarsus 0.71 , claw 0.32 , total excluding claw 6.47 ; Leg I: trochanter 1.18 , femur 3.55 , patella 4.18 , tibia 2.92 , metatarsus 1.03 , tarsus 1.58 , total 14.45 . Leg IV: trochanter 0.87 , femur 3.47 , patella 1.58 , tibia 2.45 , metatarsus 2.21, tarsus 1.34, total 11.92 .

Coloration (Fig. 1). Propeltidium, mesopeltidia, metapeltidium, tergites and distal sternites brown greenish; coxae, metatarsus, tarsus and sternites I-V paler; chelicerae and tibia, tarsus and spur of the pedipalpus brown reddish.

Propeltidium (Figs 2-3). With three anterior setae and five dorsal pairs $(2+1: 2: 2: 2: 2: 2)$, Harvey [2001] and Sissom [1980] recorded (2+1:2:2:2:2); corneate eyes present. Mesopeltidia widely separated. Metapeltidium divided.

Abdomen. Chaetotaxy: Tergite I with one pair of dorsal setae and three pair of microsetae; tergite II with one dorsal pair and three pairs of microsetae. Chaetotaxy of abdominal tergites does not differ significantly from that described by Harvey [2001]. Segments IX- 

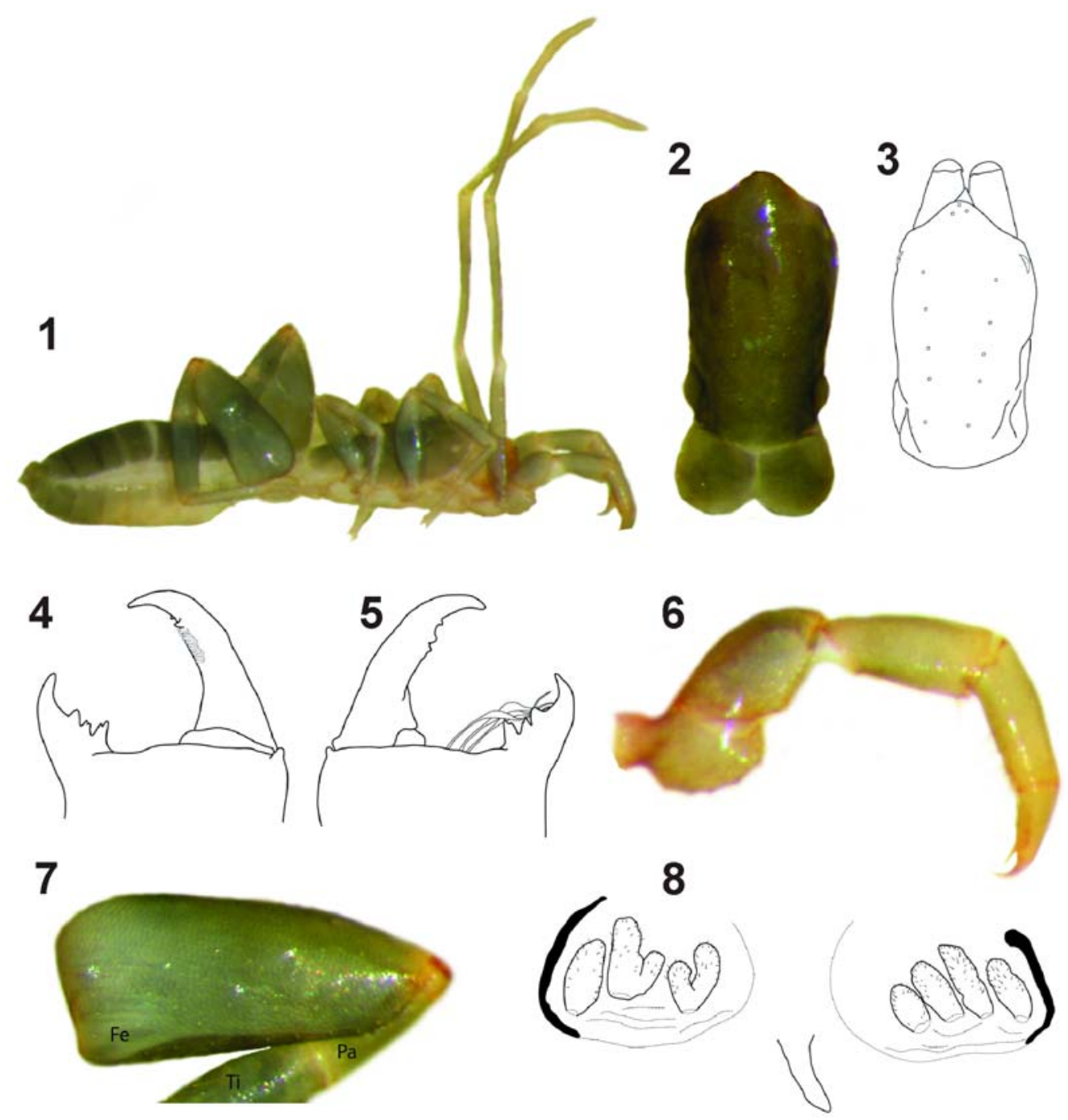

Figs 1-8. Zomus bagnallii, female (MIZA 1355): 1 - habitus, lateral view; 2 - propeltidium, dorsal view; 3 - propeltidium, schematic view showing setal pattern; 4-5 - right chelicera, mesal and ectal view; 6 - right pedipalp, ectal view; 7 left leg IV, prolateral view $(\mathrm{Fe}$ - femur, $\mathrm{Pa}$ - patella, $\mathrm{Ti}$ - tibia); 8 - spermathecae, dorsal view.

Рис. 1-8. Zomus bagnallii, самка (MIZA 1355): 1 - габитус, сбоку; 2 - пропельтидий, сверху; 3 - пропельтидий, схема показывающая расположение щетинок; 4-5 - правая хелицера, внутренняя и наружные стороны; 6 - правая пальпа, ретролатерально; 7 - левая нога IV, пролатерально (Fe - бедро, Ра - колено; Ti - голень); 8 - сперматека, сверху.

XII not elongated. Segment XII without posterodorsal process. Ventral region. Respiratory spiracles large and oval, slightly sclerosed, darker than sternites. Flagellum is broken and lost.

Chelicerae (Figs 4-5). No significant differences respect description given by Harvey [2001], lamella with 14 teeth. Reddell and Cokendolpher [1995] in the diagnosis of the genus wrote without accessory teeth in the chelicerae, however three small teeth could be observed in the studied material.

Pedipal (Fig. 6). Trochanter with mesal spur, without anterior projection, triangle-like with stout ventral setae. Femur short and robust, dorsally curved, thinner at base and wider at apex. Patella smooth, sub-cylindrical, slightly wider distally, 2.3 longer than high. Tibia smooth, cylindrical, about 3.8 longer than high. Tarsus conical, about one-half tibial length, with two distal spurs. Tarsal claw sharp and curved, slightly shorter than one-half tibial length.

Legs. Typical Hubbardiinae pattern, anterodorsal margin of femur IV curved at about a $90^{\circ}$ angle (Fig. 7).

Spermathecae (Fig. 8). Gonopod tubular, very difficult to see. Chitinized arch reduced, only present by the lateral. Four lobules each side, some merged at base, with some pilifer pores.

REMARKS. The female from Samoa differs little from the descriptions given by Sissom [1980], Reddell \& Cokendolpher [1995] and Harvey [2001]; these differences are noted above. Until a study with more specimens from Samoa and another localities is conducted, it is premature to conclude whether this could 
be a different species or whether these differences are variations between populations.

Whilst schizomids have been previously recorded from Samoa, none of the specimens have been identified to species level. Savory [1977] mentioned the family Schizomidae (now called Hubbardiidae) from many localities in Western Samoa, and records of Hubbardiinae were later listed by Reddell \& Cokendolpher [1995].

Most schizomids are considered to be hemiedaphic inhabitants of soil [e.g. Adis et al., 1999]. However, at least two Neotropical species of the genus Surazomus Reddell \& Cokendolpher, 1995 have been collected on understorey vegetation or observed climbing trees in seasonally flooded Amazonian forest ( $S$. arboreus Cokendolpher \& Reddell, 2000 and S. uarini Santos \& Pinto-da-Rocha, 2009 [Santos \& Pinto-da-Rocha, 2009]). Specimens of $Z$. bagnallii have been collected under coconut hulls, sifting leaves of Dendrobium umbellatum, leaves near Pandanus, under rotten wood, and using pitfall traps [Harvey, 2001]. The material studied here was collected beating vegetation, being the first record of this species collected in this habitat.

ACKNOWLEDGMENTS. To Hermes Escalona (MIZA, Venezuela) by permit us kindly, the study of the material from Samoa. To Quintin Arias (MIZA, Venezuela) by technical facilities during the study of the material and help in the carrying out of the pictures. To Luis F. de Armas (Ha- vana, Cuba) by comments about the manuscript and correction about the language. To Mark Harvey (WAM, Australia), by confirming the identification and the comments on the manuscript.

\section{References}

Adis J., Reddell J., Cokendolpher J., Morais J.W. 1999. Abundance and phenology of Schizomida (Arachnida) from a primary upland forest in central Amazonia // Journal of Arachnology. Vol.27. P.205-210.

Cokendolpher J.C., Sissom W.D., Bastawade D.B. 1988. A new Schizomus from the India State of Maharashtra, with additional comments on eyed schizomids (Arachnida: Schizomidae) // Insecta Mundi. Vol.2. No.2. P.90-96.

Harvey M.S. 2001. The Schizomida (Arachnida) of the Seychelle Islands // Invertebrate Taxonomy. Vol.15. P.681-693.

Reddell J.R., Cokendolpher J.C. 1995. Catalogue, bibliography, and generic revision of the order Schizomida (Arachnida) // Texas Memorial Museum, Speleological Monographs. Vol.4. P.1-170.

Santos J., Pinto-da-Rocha R. 2009. A new micro-whip scorpion from Brazilian Amazonia (Arachnida: Schizomida: Hubbardiidae) with the description of a new synapomorphy of Uropygi // Journal of Arachnology. Vol.37. P.39-44.

Savory T.[H]. 1977. Arachnida. $2^{\text {nd }}$ ed. New York: Academic Press. vii +340 pp.

Sissom W.D. 1980. The eyed schizomids, with description of a new species from Sumatra (Schizomida: Schizomidae) // Journal of Arachnology. Vol.8. P.187-192.

Villarreal M.O., Giupponi A.P.L., Tourinho A. 2008. New Venezuelan genus of Hubardiidae [sic] (Arachnida: Schizomida) // Zootaxa. Vol.1860. P.60-68. 